\title{
チクソモールド成形に及ぼすAZ91Dマグネシウム合金チップ 表面へのカーボンナノ粒子修飾の効果
}

\author{
橋本 嘉昭* . 日野 実**.水戸岡 豊*** \\ 村上 浩二 $* * *$. 金谷 輝人 $* * * *$
}

\begin{abstract}
Journal of The Japan Institute of Light Metals, Vol. 65, No. 4 (2015), 118-122
(C) 2015 The Japan Institute of Light Metals

\section{Effects of fixing carbon nanoparticle to AZ91D magnesium alloy chip surface on thixomold forming}

\author{
Yoshiaki HASHIMOTO* ${ }^{*}$ Makoto HINO**, Yutaka MITOOKA*** \\ Koji MURAKAMI*** and Teruto KANADANI****
}

\begin{abstract}
Thixomolded magnesium products have been applied as an alternative for plastic moldings in body frames for electronic equipments. AZ91D magnesium alloy chips are ordinarily used for thixomolding process. The carbon nanoparticle was fixed in the magnesium chip surface in order to improve the castability of thixomolding process. The manufacture of magnesium-carbon alloy is not easy, because carbon does not have the wettability for magnesium. However, the magnesium alloy chips fixed carbon nanoparticles make it possible to produce the magnesium-carbon alloy by thixomolding process. Since the fluidity of the magnesium alloy chip with carbon nanoparticle was improved in comparison with the AZ91D magnesium alloy chip, thin thickness molding became possible. In addition, mechanical properties of the thixomolded magnesium alloy made of the magnesium alloy chips fixed carbon nanoparticle were also improved.
\end{abstract}

(Received September 8, 2014 Accepted December 14, 2014)

Keywords: AZ91D magnesium alloy, carbon nanoparticle, surface modification, thixomold forming

\section{1. 緒言}

マグネシウム合金は，軽量で比剛性が高く，放熱性，防振 性, 電磁波シールド性, およびリサイクル性に優れるなど, 多くの特性を有しており, ノートPCをはじめ, 様々な電子

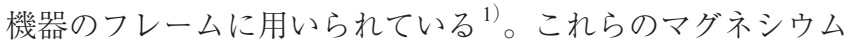
合金製電子機器フレームに対して薄肉で複雑形状が要求さ れ, 現在, それらの要求性能に対応するプロセスとしてチク ソモールド成形が広く適用されている ${ }^{2)}$ 。

スマートフォンやタブレット PCなどの携帯電子機器は, いま以上に軽量小型化が要求され，それに伴い，マグネシウ ム製フレームに対して，これまで以上に薄肉化および機械的 性質の向上が求められている。マグネシウムチクソモールド 成形は，現在までに射出速度，射出温度，金型温度，および 金型の工夫など，様々な成形条件の適正化を図ることによ り，薄肉で複雑形状品の成形を実現してきた。しかし，成形 条件によるいま以上の薄肉化や機械的性質の向上は容易では ない。

$$
\text { 一方, マグネシウム合金へのカーボン添加が結晶粒の微細 }
$$

化ならびに機械的性質の向上に寄与することが報告されてい る3)。しかし，カーボンはマグネシウムに対して濡れ性を有 していないため, カーボンを直接マグネシウムに添加するこ とは極めて困難である。

チクソモールド成形は, マグネシウム合金のインゴットか ら粉砕したチップを出発原料とし，チップは加熱されたシリ ンダ内をスクリューによって押出され，マグネシウム合金を 金型内に高速充填し，製品形状に成形される ${ }^{4)}$ 。チクソモー ルド成形において，マグネシウム合金チップの表面にカーボ ンを修飾し, それらを出発原料とすることによってカーボン が添加されたマグネシウム合金の作製が期待できる。

本研究では, チクソモールド成形において, 出発原料と して主に用いられるAZ91Dマグネシウム合金チップ表面に カーボンナノ粒子を付着させ，マグネシウム合金中へのカー ボン添加を試みた。併せて成形性および成形品の引張特性に 及ぼすカーボン修飾の影響を調べた。

\section{2. 実験方法}

チクソモールド成形に用いるチップは, 市販の AZ91Dマ

*株式会社 STU 岡山工場（†719-1102＼cjkstart岡山県総社市東阿曾303-1） STU Co., LTD., Okayama Factory (303-1, Higashiaso, Soja-shi, Okayama 719-1102) E-mail: hashimoto@stu-corp.jp

**広島工業大学工学部（広島市） Faculty of Engineering, Hiroshima Institute of Technology (Hiroshima-shi, Hiroshima)

***岡山県工業技術センター（岡山市） Industrial Technology Research Institute of Okayama Prefecture (Okayama-shi, Okayama)

****岡山理科大学工学部（岡山市） Faculty of Engineering, Okayama University of Science (Okayama-shi, Okayama) 
Table 1 Chemical composition of AZ91D magnesium chip (mass\%).

\begin{tabular}{c|c|c|c|c|c|c|c|c|c|c|c}
\hline \hline & $\mathrm{Al}$ & $\mathrm{Zn}$ & $\mathrm{Mn}$ & $\mathrm{Si}$ & $\mathrm{Fe}$ & $\mathrm{Cu}$ & $\mathrm{Ni}$ & $\mathrm{Be}$ & Others & $\mathrm{C}$ & $\mathrm{Mg}$ \\
\hline AZ91D chip & 8.91 & 0.65 & 0.22 & 0.03 & 0.002 & 0.003 & 0.0008 & 0.001 & $<0.001$ & 0.01 & bal. \\
\hline
\end{tabular}

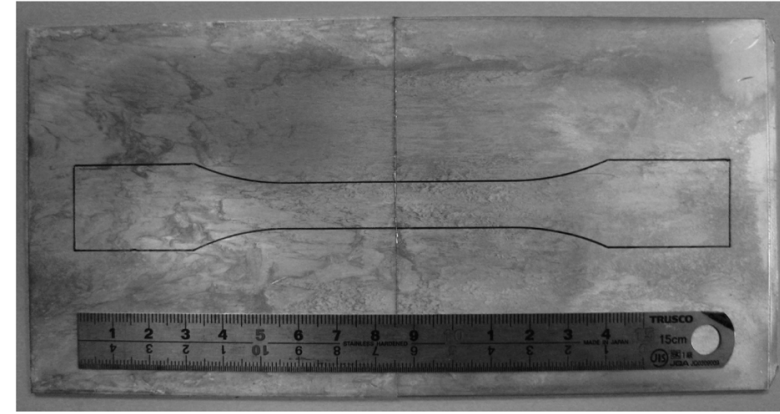

$10 \overline{m m}$

Fig. 1 Appearance of thixomolded specimen and drawing of tensile test specimen.

グネシウム合金インゴットからチッピングマシンによって約 $4 \mathrm{~mm}$ 長さに削り出し，作製した。AZ91Dマグネシウム合金 チップの化学組成を Table 1 に示す。チップ表面にカーボン ナノ粒子を付着させるため, チップに対してカーボンナノ粒 子をチップ重量の 0.1 mass \% 添加し，ミキサーによって一定 時間攪拌した。チクソモールド成形は，マグネシウム用チク ソモールドマシン（株）日本製鋼所製，JLM2800MGIe，型締 め力 $2744 \mathrm{kN})$ を使用した。

AZ91Dマグネシウム合金チップおよびその表面にカーボ ン付着処理を施したチップを用い，試験片サイズが $200 \times 100$ $\times 2 \mathrm{~mm}$ になるよう，それぞれチクソモールド成形を行った。 各成形品に対して発光分光分析（侏島津製作所製PDA-7000） による組成分析を行った。引張特性を評価するため，各成 形品からFig. 1 に示すJIS Z2201に準拠した試験片（平行部 $60 \mathrm{~mm}$, 幅 $10 \mathrm{~mm}$, 厚さ $2 \mathrm{~mm}$, 標点距離 $50 \mathrm{~mm}$ ) を採取し, 引張試験（インストロン社製3382）を行った。

薄肉複雑形状品の成形に最も重要な湯流れ性は, 肉厚 $0.5 \mathrm{~mm}$ の渦巻き金型にチクソモールド成形し，その流動長 によって評価した。チクソモールド成形において生じる鋳巣 などの内部欠陥は X線 CT スキャナ（東芝ITコントロールシ

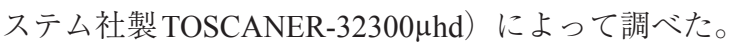

\section{3. 実験結果および考察}

\section{1 マグネシウム合金チップヘのカーボン修飾}

Fig. 2 には，マグネシウム合金チップへの表面修飾に用 いたカーボンナノ粒子の二次電子像を示す。平均粒径は約 $30 \mathrm{~nm}$ であり，粒子は分散しておらず，凝集した状態であっ た。AZ91Dマグネシウム合金インゴットより作製したチッ プ (以後, AZ91Dチップと記す) に対してカーボンナノ粒 子を添加し，ミキサー攪拌によってチップ表面にカーボンナ ノ粒子の付着処理 (以後, カーボン修飾チップと記す) を行っ た。付着処理前後のチップ外観を Fig. 3 に示す。AZ91Dチッ プは銀白色である一方，カーボン修飾チップはそれよりも明 らかに黒く変色しており，この外観変化は，チップ表面に カーボンナノ粒子が付着されたことを示唆している。

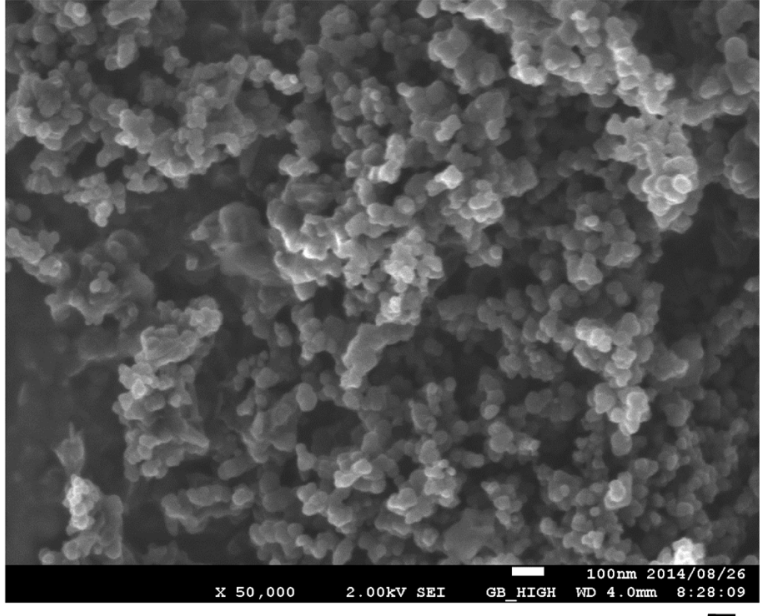

$100 \mathrm{~nm}$

Fig. 2 Secondary electron image of carbon nanoparticles.
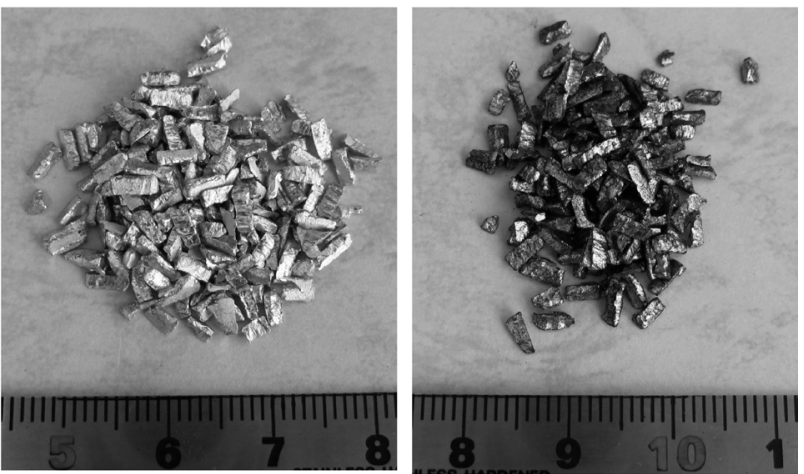

Fig. 3 Appearances of the magnesium chips. (a) AZ91D chips, (b) carbon fixed chips.
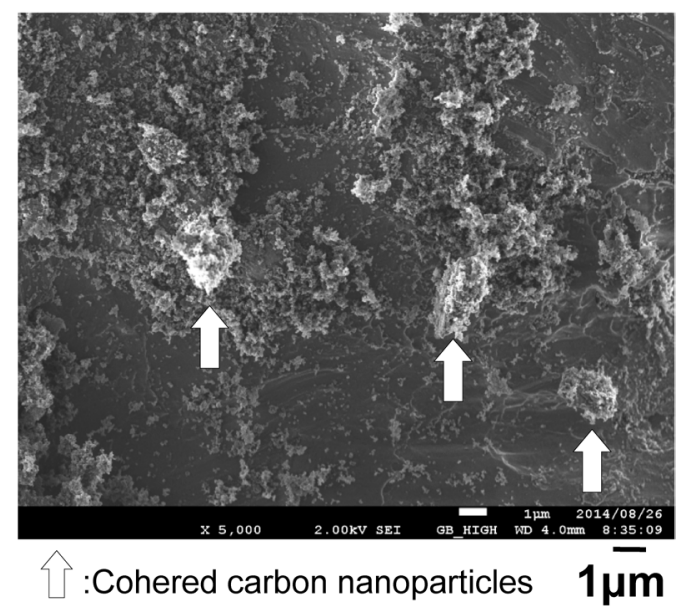

Fig. 4 Secondary electron image of carbon fixed chip.

Fig. 4 には，カーボン修飾チップ表面の二次電子像を示す。 カーボンナノ粒子はチップ表面に均一には付着しておらず, 矢印で示しているように部分的に凝集した状態で存在してい 
る。なお，カーボンナノ粒子とマグネシウム合金チップ表面 との結合性を向上させる目的で，カーボンナノ粒子表面の末 端には $\mathrm{COOH}$ 基, $\mathrm{OH}$ 基, $\mathrm{CHO}$ 基等の官能基を修飾している。
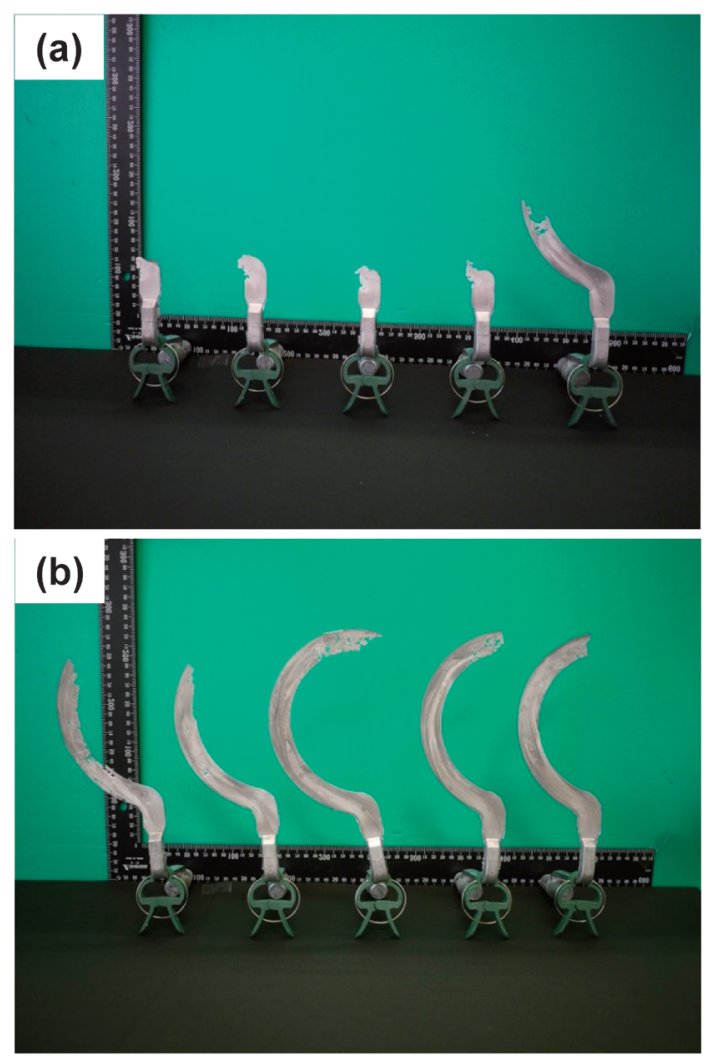

Fig. 5 Appearances of fluidity testing by thixomolding. (a) AZ91D chip, (b) carbon fixed chip.
3.2 チクソモールド成形に及ぼすチップ表面へのカーボ ン修飾の効果

3.2.1 チクソモールド成形

AZ91Dチップおよびカーボン修飾チップを用い，それ ぞれ同一条件でチクソモールド成形を行った。Table 2 に は，AZ91Dチップおよびカーボン修飾チップによるチクソ モールド成形品の化学組成を示す。AZ91Dチップの化学組 成（Table 1) およびAZ91Dチップによる成形後の化学組成 に大きな差異はない。カーボン修飾チップによる成形品の 化学組成は, カーボンを除き, AZ91Dチップによる成形品

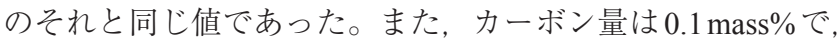
AZ91Dチップに添加したカーボン量と同じ值を示した。こ のことはチップ表面に付着したカーボンナノ粒子の大部分が

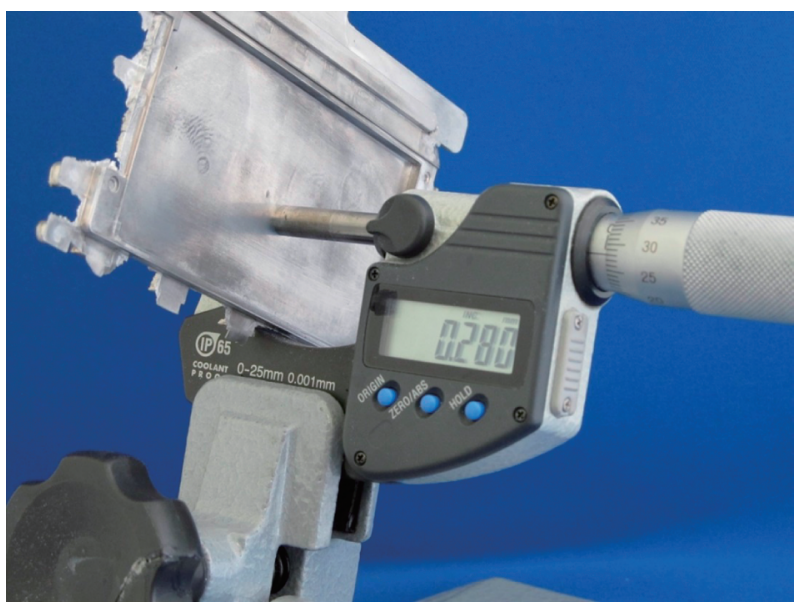

Fig. 6 Appearance of thixomolded specimen $(100 \mathrm{~mm}$ $\times 50 \mathrm{~mm}$ ) made of carbon fixed chip.
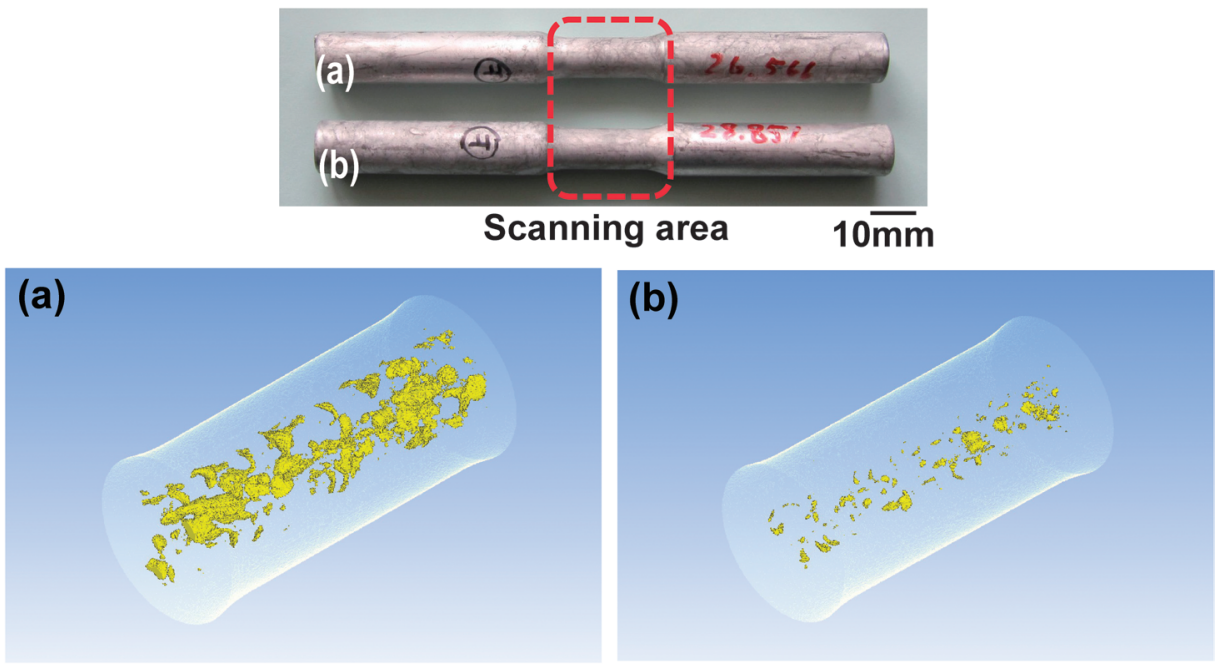

Fig. 7 Observation results of thixomolded specimens using X-ray CT scanner (a) AZ91D chip, (b) carbon fixed chip.

Table 2 Chemical composition of thixomolded specimens made of AZ91D chip and carbon fixed chip (mass\%).

\begin{tabular}{l|c|c|c|c|c|c|c|c|c|c|c}
\hline \hline & $\mathrm{Al}$ & $\mathrm{Zn}$ & $\mathrm{Mn}$ & $\mathrm{Si}$ & $\mathrm{Fe}$ & $\mathrm{Cu}$ & $\mathrm{Ni}$ & $\mathrm{Be}$ & Others & $\mathrm{C}$ & $\mathrm{Mg}$ \\
\hline AZ91D chip & 9.2 & 0.65 & 0.22 & 0.03 & 0.004 & 0.003 & 0.0007 & 0.0010 & $<0.001$ & 0.01 & bal. \\
Carbon fixed chip & 9.1 & 0.66 & 0.21 & 0.03 & 0.003 & 0.003 & 0.0008 & 0.0007 & $<0.001$ & 0.10 & bal. \\
\hline
\end{tabular}


チクソモールド成形によって成形品に取り込まれていること を示している。

\subsection{2 湯流れ性}

チクソモールド成形によるマグネシウム合金製電子機器フ レームでは, 薄肉で複雑形状が要求される。そのため, チ クソモールド成形における湯流れ性に及ぼすマグネシウム 合金チップ表面へのカーボン修飾の影響を成形部の厚さが $0.5 \mathrm{~mm}$ の渦巻き金型を用い，その流動長によって評価した。 Fig. 5 に同一条件（射出温度 $853 \mathrm{~K}$, 射出速度 $2.5 \mathrm{~m} / \mathrm{s}, N=5$ ) にてチクソモールド成形を行った試料の外観を示す。カー ボン修飾チップによる流動長はAZ91Dチップのそれと比べ, 大幅に向上した。

Fig. 6 には，製品形状が約 $100 \times 50 \mathrm{~mm}$ の金型によるカーボ ン修飾チップを用いたチクソモールド成形品の外観を示す。 AZ91Dチップを適用した場合，板厚 $0.3 \mathrm{~mm}$ の成形が困難で あったが, カーボン修飾チップを用いた場合，同じ成形条 件で板厚 $0.28 \mathrm{~mm}$ の成形が可能であった。このようにチクソ モールド成形において AZ91Dチップ表面へのカーボンナノ 粒子の修飾は，湯流れ性を向上させ，未修飾のチップでは困 難な薄肉成形を可能にした。

表面に付着したカーボンナノ粒子による湯流れ性への影響 について，六員環構造を有するグラファイトは固体潤滑剤と して用いられ，同じ六員環構造を有するカーボンナノ粒子も 同様な潤滑効果が期待できる。そのためチップ表面のカーボ ンナノ粒子は，シリンダ内でのチップ同士ならびにチップと 金型内面の摩擦係数を低減させ，それによって流動性が向上 する。しかし，金型への射出成形時には，マグネシウム合金 チップの大部分が溶融するため, チップ表面のカーボンナ ノ粒子は擋汼され，その潤滑効果も消失するものと思われ る。本実験で示された湯流れ性の向上は，溶湯中のわずか 0.1 mass\%のカーボンによってもたらされていることになる が，マグネシウム合金中の微量カーボンが融点や共晶点を大 幅に変化させることは考えにくい。カーボンナノ粒子が潤滑 作用を示し，金型と溶湯表面の流動性に影響を及ほしている ことは予想できるが，金型表面には流動性の向上などを目的 に離型材が塗布されていることから，潤滑作用のほかにも溶 湯の湯流れ性を向上させる因子が存在すると思われ, 今後, この点について，より詳細な検討を行う予定である。

\section{2 .3 チクソモールド成形における内部欠陥}

AZ91Dチップによるチクソモールド成形は，その多くが 薄肉・複雑形状品に適用される。一方，チクソモールド成形 に対して数ミリ以上の肉厚品への適用が切望されているが, 成形品の肉厚増加に伴い, 鋳巣などの内部欠陥が発生しやす く，その内部欠陥が適用への障害となっている。

そこで, 引張試験用ダンベル形状金型（平行部直径 $10 \mathrm{~mm} ）$ により，AZ91Dチップおよびカーボン修飾チップを 用い，同一条件にてチクソモールド成形した。Fig. 7 には夕゙ ンベル形状成形品の外観およびX線 CT スキャナによる内部 久陥の3Dイメージを示す。なお，測定は破線で囲んだ平行 部（直径 $10 \mathrm{~mm}$ ）について行った。AZ91Dチップによる成形 品には多くの内部欠陥が観察されるが，カーボン修飾チップ による成形品の内部欠陥は大幅に減少した。このようにチク ソモールド成形において, 肉厚部に生じる内部欠陥の抑制に 対してチップ表面へのカーボン修飾が極めて有用であること

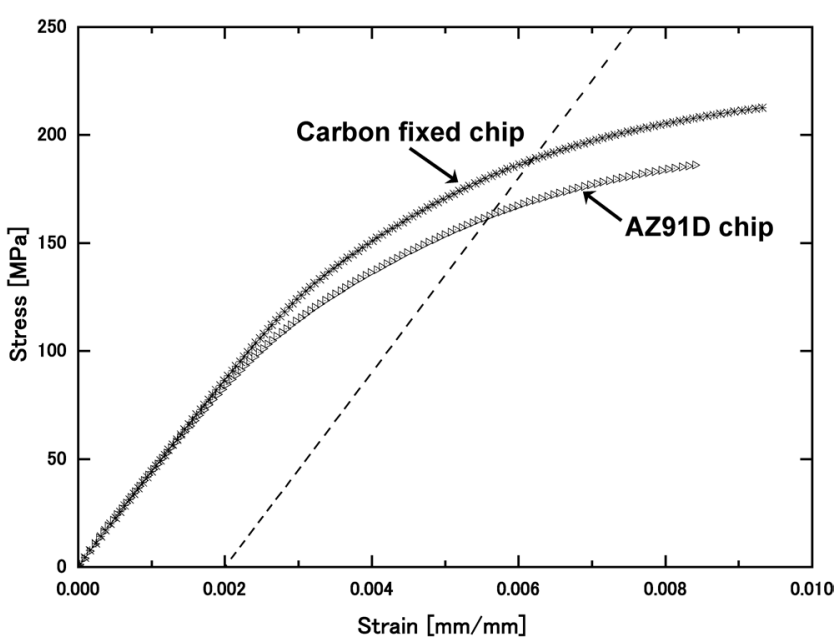

Fig. 8 Stress-strain chart for thixomolded specimens.

Table 3 Mechanical properties of thixsomolded specimens made of AZ91D chip and Carbon fixed chip.

\begin{tabular}{l|c|c|c}
\hline \hline & $\begin{array}{r}0.2 \% \text { proof } \\
\text { stress (MPa) }\end{array}$ & $\begin{array}{c}\text { Tensile strength } \\
(\mathrm{MPa})\end{array}$ & $\begin{array}{c}\text { Elongation } \\
(\%)\end{array}$ \\
\hline AZ91D chip & 158 & 186 & 2.0 \\
Carbon fixed chip & 187 & 213 & 3.0 \\
\hline
\end{tabular}

がわかった。なお，カーボン修飾による内部欠陷の抑制は， 前述の湯流れ性の向上と密接に関連しており，金型内部への 溶湯の充填が促進されることに起因すると推測されるが，そ の詳細は不明な点も多く，更なる検討を要する。

3.2. 4 引張特性

Fig. 8 には，AZ91Dチップおよびカーボン修飾チップを用 いたチクソモールド成形品から採取した試験片の引張試験 における応力ーひずみ線図の一例を示す。弾性域での両者の 縦弾性係数は同じであるが, $0.2 \%$ 耐力, 引張強さ, 伸びは, カーボン添加によって向上した。 $N=5$ で引張試験を行った 引張特性の平均值を Table 3 に示す。カーボン添加によって $0.2 \%$ 耐力, 引張強さ，伸びはすべて向上した。

このようにAZ91Dマグネシウム合金中に存在するわずか $0.1 \mathrm{mass} \%$ のカーボンが引張特性の向上に寄与することが明 らかになった。これまでマグネシウム合金中へのカーボン添 加は両者間での濡れ性がそしいため容易に作製することは困 難であった。一方，チクソモールド成形において，カーボン 修飾チップを適用することにより，カーボン添加マグネシウ ム合金を容易に作製することができ，さらに鋳造性の改善な らびに引張特性の向上を図ることができた ${ }^{5)}$ 。

\section{4. 結言}

本研究では，マグネシウムチクソモールド成形において 出発原料としてAZ91Dマグネシウム合金チップ表面にカー ボンナノ粒子を付着させ，マグネシウム合金中へのカーボン 添加を試みた。併せて成形性および成形品の引張特性に及ぼ すカーボン修飾の影響を調べた結果，以下の結論を得た。

(1) AZ91Dマグネシウム合金チップに対してカーボンナ ノ粒子を 0.1 mass\% 添加し，ミキサー攪汼することにより， チップ表面にカーボンナノ粒子を付着することができた。 
(2） 0.1 mass\% \%ーボン添加チップによるチクソモールド 成形品は，0.1 mass\%のカーボンを含有することから，チッ プ表面に付着したカーボンの大部分は素材中に取り込まれ る。このように本プロセスでは比較的容易にカーボン添加マ グネシウム合金を作製することができる。

（3）チクソモールド成形において，チップ表面に付着し たカーボンナノ粒子は固体潤滑剂として作用し，湯流れ性の 向上，鋳巣の抑制など鋳造性を向上させると考えられた。ま た, 成形品の引張特性が向上し, カーボン添加の効果が認め られた。

\section{謝 辞}

本研究は, 経済産業省戦略的基盤技術高度化支援事業
「フォトニクスを用いた高性能マグネシウム製品のクローズ ド製造プロセスの創成」(平成22２4年度）における成果の

一部であり，誌面をお借りし，謝意を申し上げる。

\section{参 考 文 献}

1）小島 陽：軽金属, 58 (2008), 526-548.

2）日野 実, 平松 実, 村上浩二, 西條充司, 金谷輝人：軽金属, 56 (2006), 386-392.

3）牧野邦彦，河田俊郎，羽根秀男：軽金属，42（1992）, 810-814.

4）豊島俊雄：マグネシウム合金の基盤技術と応用展開，監修鎌土 重晴，小原 久，シーエムシー出版，（2012），35-44.

5) 水戸岡豊, 日野 実, 村上浩二, 内山 光, 橋本嘉昭 : 特許第 5137049，中国ZL201280002710.7，大韓民国 10-1310622 